E3S Web of Conferences 1, 32001 (2013)

DOI: $10.1051 / \mathrm{e} 3$ sconf/20130132001

(C) Owned by the authors, published by EDP Sciences, 2013

\title{
Radioactive Cesium from Fukushima Japan Detected in Bluefin Tuna off California: Implications for Public Health and for Tracking Migration
}

\author{
$\underline{\text { N. S. Fisher }}^{1}$, D. J. Madigan ${ }^{2}$ and Z. Baumann ${ }^{3}$ \\ ${ }^{1}$ School of Marine and Atmospheric Sciences, Stony Brook University, Stony Brook, NY 11794-5000 USA \\ nicholas.fisher@stonybrook.edu \\ ${ }^{2}$ Hopkins Marine Station, Stanford University, Pacific Grove, CA 93950 USA dmadigan@stanford.edu \\ ${ }^{3}$ School of Marine and Atmospheric Sciences, Stony Brook University, Stony Brook, NY 11794-5000 USA \\ zofia.baumann@stonybrook.edu
}

\begin{abstract}
Bluefin tuna are highly migratory pelagic fish. Pacific bluefin tuna are spawned in waters off Japan and some juveniles migrate across the Pacific to waters off California. Bluefin that had recently migrated and caught in waters off San Diego, California in August 2011 were found to have ${ }^{134} \mathrm{Cs}$ and ${ }^{137} \mathrm{Cs}$ in their muscle tissue, at concentrations that could only have come from the Fukushima nuclear reactor in Japan. Bluefin tuna caught 3 years earlier off San Diego and yellowfin tuna that are resident to the eastern Pacific had no ${ }^{134} \mathrm{Cs}$ and only background levels of ${ }^{137} \mathrm{Cs}$. The radioactivity in tuna attributable to these Cs isotopes was only $2.8 \%$ of that from the naturally occurring ${ }^{40} \mathrm{~K}$, suggesting that consumption of these fish poses little risk to public health. The presence of these isotopes in animal tissues can be used to discern migratory routes and timing for those animals that use the western Pacific.
\end{abstract}

Key words: cesium, radioactivity, Fukushima, tuna

\section{Introduction}

The earthquake and subsequent tsunami that hit Japan in March 2011 resulted in damage to the Fukushima Daiichi nuclear power plant, which led to the largest release of radionuclides into the ocean of any accident to date. Isotopes of cesium, ${ }^{134} \mathrm{Cs}\left(\mathrm{t}_{1 / 2}=2.1 \mathrm{y}\right)$ and ${ }^{137} \mathrm{Cs}\left(\mathrm{t}_{1 / 2}=30\right.$ y) dominated the release of the long-lived radionuclides. These isotopes were released equally, resulting in concentrations in Japanese surface waters of about 1:1. ${ }^{137} \mathrm{Cs}$ concentrations in $150,000 \mathrm{~km}^{2}$ of ocean waters east of Japan increased 1000-fold over prior concentrations $\left(1.5 \mathrm{mBq} \mathrm{L} \mathrm{L}^{-1}\right)$, remnants of weapons testing from the 1960s; ${ }^{134} \mathrm{Cs}$ concentrations prior to the accident were below detection in Pacific waters and resident biota (Buesseler et al. 2012). Cs is known to be concentrated by fish, and fish concentrations in the western Pacific indeed showed elevated concentrations in their tissues, with ratios of ${ }^{134} \mathrm{Cs}:{ }^{137} \mathrm{Cs}$ of about $1: 1$, reflecting the ambient water and the levels in their food (Buesseler et al. 2012). Here we report measurements of concentrations of radiocesium in bluefin tuna (Thunnus orientalis) that were caught in the eastern Pacific, in waters off San Diego, California. These fish spawn in the western
Pacific and migrate across the Pacific, usually in their first or second year of life (Block et al. 2011).

\section{Methods}

Pacific bluefin, known from size to be recent Japan migrants, were collected from sports fishermen in August 2011 , some 5 months after the tsunami. White muscle tissue from the filets of 15 bluefin tuna caught of San Diego were freeze dried, homogenized, and analyzed by gamma spectrometry using a low energy germanium detector. Five yellowfin tuna (Thunnus albacares), which are highly residential (Block et al. 2011), collected off San Diego in August 2011 were also analyzed, as were 5 additional bluefin tuna collected in $2008 .{ }^{40} \mathrm{~K}$ and other naturally-occurring radionuclides were also measured in the same samples to contrast radiocesium concentrations with the radioactivity of the anthropogenic radionuclides. ${ }^{134} \mathrm{Cs}$ and ${ }^{137} \mathrm{Cs}$ concentrations were decay-corrected to the catch date. We calculated ${ }^{134} \mathrm{Cs}$ and ${ }^{137} \mathrm{Cs}$ concentrations in 2011 PBFT for various times prior to capture in California $(0,30,60,90,120$ days). We accounted for background ${ }^{137} \mathrm{Cs}$ in tuna muscle $(1.0 \mathrm{~Bq}$ $\mathrm{kg}^{-1}$ ) by subtracting 1.0 from total ${ }^{137} \mathrm{Cs}$ values. We then accounted for the radioactive decay of $\mathrm{Cs}$ isotopes, 


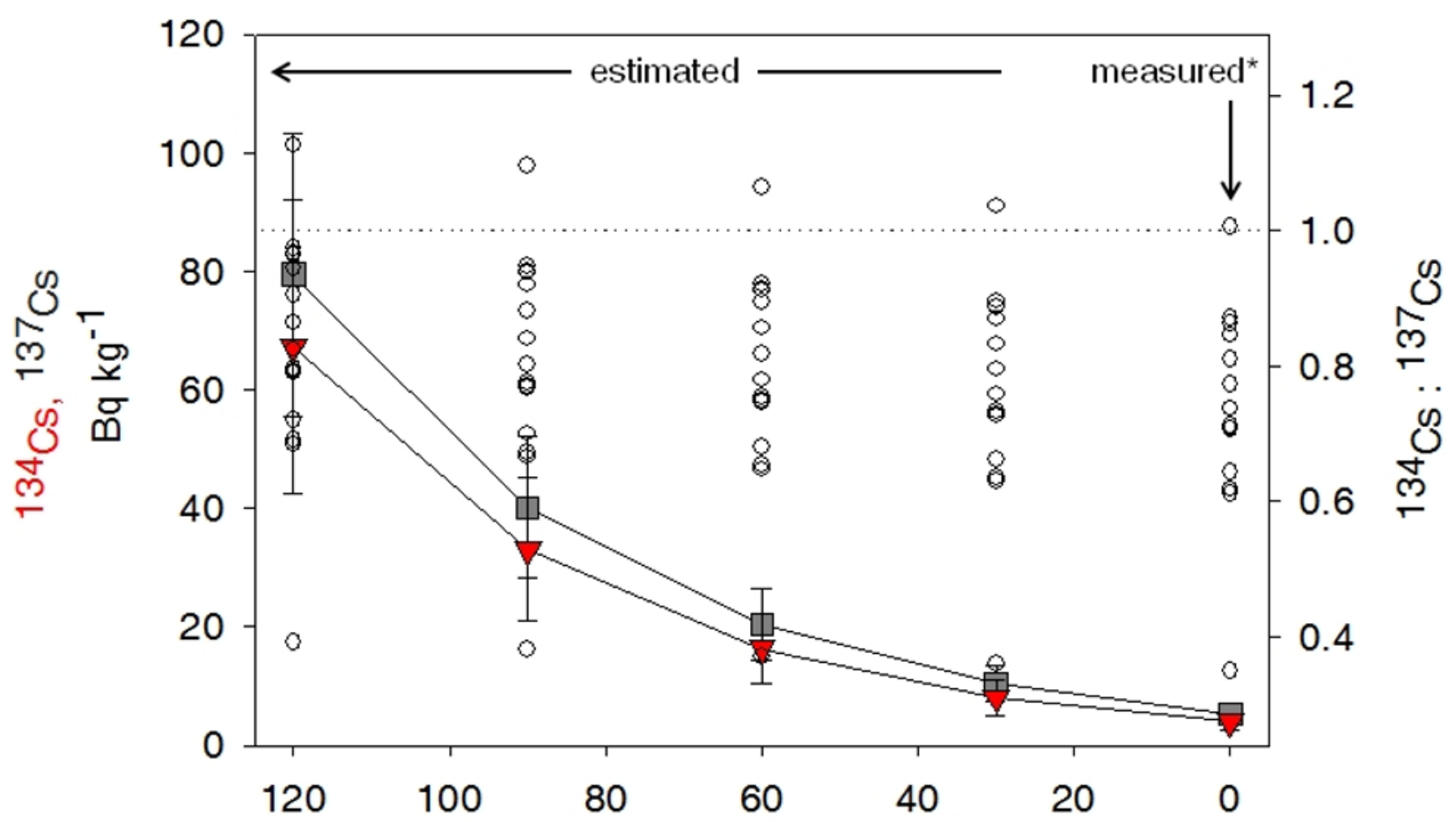

Time before capture in California (d)

Fig. 1. Measured and back-calculated values of radiocesium concentrations in muscle of post-Fukushima Pacific bluefin tuna Thunnus orientalis $(\mathrm{n}=15)$. Mean concentrations of ${ }^{134} \mathrm{Cs}$ (triangles) or ${ }^{137} \mathrm{Cs}$ (squares) shown on left $y$-axis. Error bars represent 1 standard deviation. Ratios of ${ }^{134} \mathrm{Cs}:{ }^{137} \mathrm{Cs}$ for each individual fish (empty circles) shown with scale on right $y$-axis. Dotted line represents $1: 1$ ratio of ${ }^{134} \mathrm{Cs}:{ }^{137} \mathrm{Cs}$, the ratio expected in tuna muscle while in waters off Japan contaminated with ${ }^{134} \mathrm{Cs}:{ }^{137} \mathrm{Cs}$ at a ratio of 1.0 . ${ }^{*}$ Corrected for background levels of ${ }^{137} \mathrm{Cs}$. (from Madigan et al. in press)

important only for the shorter-lived ${ }^{134} \mathrm{Cs}\left(\mathrm{t}_{1 / 2}=2.1\right.$ years $)$ using an exponential decay model. To account for the metabolic efflux of assimilated cesium out of fish we used an experimentally-derived marine fish efflux rate constant $k$ of $0.019 \mathrm{~d}^{-1}$ (Mathews and Fisher 2009). To address growth dilution of the $\mathrm{Cs}$ concentrations in muscle, we calculated change in fish body mass $(0-120$ days prior to catch) and calculated dilution of $\mathrm{Cs}$ concentrations over this range of days due to growth.

\section{Results and Discussion}

All 15 post-Fukushima bluefin tuna had elevated ${ }^{134} \mathrm{Cs}$ and ${ }^{137} \mathrm{Cs}$, whereas pre-Fukushima bluefin and postFukushima yellowfin tuna had no detectable ${ }^{134} \mathrm{Cs}$ andonly background ${ }^{137} \mathrm{Cs}$ from prior weapons testing (Table 1). The radioactivity attributable to these Cs isotopes was about 36 times less than that from ${ }^{40} \mathrm{~K}$ (Table 1); the combined radioactivity from the other naturally occurring gamma-emitting radioisotopes was about 6000 times lower than that of ${ }^{40} \mathrm{~K}$ (data not shown here). The ${ }^{134+137} \mathrm{Cs}$ levels were below the Japanese limit for safe seafood consumption $\left(100 \mathrm{~Bq} \mathrm{~kg}^{-1}\right.$ wet wt, or about $400 \mathrm{~Bq} \mathrm{~kg}{ }^{-1}$ dry wt) and, given the fact that naturally occurring radioactivity was an order of magnitude greater, it would appear that the radioactivity of these fish poses no risk to public health.

Calculations of radiocesium concentrations in bluefin over a four-month period prior to capture in California are shown in Fig. 1. The calculations indicate that total initial radioactivity of ${ }^{134+137} \mathrm{Cs}$ in these fish, at the time they departed Japanese waters, was about 150 Bq kg ${ }^{-1}$ dry wt. Ratios of ${ }^{134} \mathrm{Cs}:{ }^{137} \mathrm{Cs}$ were around 1 approximately 120 days prior to capture, indicating that these tuna took 3-4 months to swim across the Pacific and had been exposed to Fukushima-derived radionuclides for 1-2 months prior to departure from the western Pacific. The highly residential yellowfin tuna collected after the Fukushima accident, and the bluefin tuna collected before the accident had no ${ }^{134} \mathrm{Cs}$ and only background levels of ${ }^{137} \mathrm{Cs}$. These findings provide unequivocal evidence that the post-Fukushima bluefin could not have acquired the Cs isotopes in the eastern Pacific and instead transported the Cs isotopes from Japanese waters to California waters. The presence of these isotopes, particularly ${ }^{134} \mathrm{Cs}$, may serve as an excellent tracer of migratory routes and timing for any large animals that may use the western Pacific, including pelagic fish, mammals, sea turtles, and birds 
Table 1. Measured ${ }^{134} \mathrm{Cs},{ }^{137} \mathrm{Cs}$, and the naturally occurring radionuclide ${ }^{40} \mathrm{~K}$ for post-Fukushima bluefin, pre-Fukushima bluefin, and post-Fukushima yellowfin tuna caught in California waters. (from Madigan et al. in press)

\begin{tabular}{|c|c|c|c|c|}
\hline & Age (years) & $\begin{array}{l}{ }^{134} \mathrm{Cs}_{(\mathrm{Bq} \mathrm{kg}}{ }^{-1} \text { dry } \\
\mathrm{wt})\end{array}$ & $\begin{array}{l}{ }^{137} \mathrm{Cs}_{(\mathrm{Bq} \mathrm{kg}}{ }^{-1} \text { dry } \\
\mathrm{wt})\end{array}$ & $\begin{array}{l}{ }^{40} \mathrm{~K}\left(\mathrm{~Bq} \mathrm{~kg}^{-1} \text { dry }\right. \\
\text { wt) }\end{array}$ \\
\hline $\begin{array}{l}\text { Bluefin } 2011 \\
(\mathrm{n}=15) \\
\text { Mean } \\
\text { median } \\
\text { SD } \\
\end{array}$ & $\begin{array}{l}1.5 \\
1.5 \\
0.1 \\
\end{array}$ & $\begin{array}{l}4.3 \\
4.0 \\
1.4 \\
\end{array}$ & $\begin{array}{l}6.0 \\
6.3 \\
1.5 \\
\end{array}$ & $\begin{array}{l}367 \\
347 \\
49\end{array}$ \\
\hline $\begin{array}{l}\text { Bluefin } 2008 \\
(\mathrm{n}=5) \\
\text { Mean } \\
\text { Median } \\
\text { SD }\end{array}$ & $\begin{array}{l}1.4 \\
1.4 \\
0.05 \\
\end{array}$ & $\begin{array}{l}0 \\
0 \\
0\end{array}$ & $\begin{array}{l}1.4 \\
1.4 \\
0.2 \\
\end{array}$ & $\begin{array}{l}266 \\
258 \\
43 \\
\end{array}$ \\
\hline $\begin{array}{l}\text { Yellowfin } 2011 \text { (n } \\
=5 \text { ) } \\
\text { Mean } \\
\text { Median } \\
\text { SD }\end{array}$ & $\begin{array}{l}1.2 \\
1.2 \\
0.01\end{array}$ & $\begin{array}{l}0 \\
0 \\
0\end{array}$ & $\begin{array}{l}1.2 \\
1.1 \\
0.4 \\
\end{array}$ & $\begin{array}{l}342 \\
333 \\
78\end{array}$ \\
\hline
\end{tabular}

\section{References}

Block BA, Jonsen ID, Jorgensen SJ, Winship AJ, Shaffer SA, et al. (2011) Tracking apex marine predator movements in a dynamic ocean. Nature 475: 86-90.

Buesseler KO, Jayne SR, Fisher NS, Rypina II, Baumann $\mathrm{H}$, et al. (2012) Fukushima-derived radionuclides in the ocean and biota off Japan. Proc Natl Acad Sci USA doi/10.1073/pnas.1120794109
Madigan DJ, Baumann Z, and Fisher NS (in press) Pacific bluefin tuna transport Fukushima-derived radionuclides from Japan to California. Proc Natl Acad Sci USAMathews T, and Fisher NS (2009) Dominance of dietary intake of metals in marine elasmobranch and teleost fish. Sci Total Environ 407: 5156-5161. 